\title{
The sky entities as represented in African literature
}

\author{
Evelyn N. Urama \\ Dept. of English \& Literary Studies, \\ University of Nigeria, Nsukka, Enugu State, Nigeria \\ email: evelynurama@gmail.com
}

\begin{abstract}
Astronomical observations used by the ancient people of Africa were developed out of the people's desire to have concrete manifestations of their gods and religious beliefs as well as for time-keeping - day, night and calendar for agricultural and festive seasons. The sky entities (the solar and stellar systems) observed become part of the lives and events here on Earth and so are also part of the context of African literature. This paper examines the ways in which different African peoples have reflected on the role of the sky entities in their literature.
\end{abstract}

Keywords. Astronomy and literature, science and society, cultural astronomy

\section{Introduction}

All great literatures give a true or a believable picture of life and events of a particular time and in a particular place. Some African writers have reflected astronomical practices of their times and places in their works of art, and since writers are very sensitive about the conditions around them, we look into their works to find such practices and beliefs. In African traditional imagination, power is an aspect of beauty. It is the expression of vitality mixed with mystery (Obiechina 1975). The sky entities manifest natural and supernatural power and the feeling this power inspires is reverence and fear. The sun, the moon and the stars are therefore perceived in their powerful, vital, beneficial or harmful aspects. Many creative expressions in Africa depict these sky entities; how they are represented in African literature reveals that cosmic nature is so intimately integrated into the lives and experiences of Africans; and the conscious and sub-conscious levels of their mind are saturated with it.

\section{Representation of the Sun in African literature}

The literary remains of the religious hymns of Egypt depict the Egyptian sun god Aton (or Aten) as the sole deity of Egyptian religion. In Hymn to the sun by the Pharaoh Akhenaton (c. $1375 \mathrm{BCE}$ ), he reflects his radical effort to make Aton (or Aten) the sole deity by saying that it is the god of creation. In this poem when the earth is full of darkness as if in death, it is the sun that created the world after his desire - all mankind, cattle, wild beast, creeping and flying animals. 'The world came into being by the hand of this sun god according as he makes them all' (Westling et al. 1999)

When thou settest in the western horizon

The land in darkness as if in death

(lines 1-2)

How manifold it is

What thou has made!

It is hidden from the face of man 
Thou sole god, without they like,

Thou didst create the world after their desire,

Whilst thou went alone:

All mankind, cattle and wild beast,

Whatever goes by foot upon the earth.

Whatever flies on high wings

The world came onto being by thy hand,

According as thou make them all

(From Hymn to the Sun, translated by John Wilson)

Chinua Achebe's Anthills of the Savannah depicts the sun as a god or deity too. The sun is portrayed as the messenger of God; accorded a deific status (Opata 2008). The hymn to the sun composed by Ikem Oshodi reveals the great powers of the sun. In traditional imagination the sun is not always conceived of as beneficent but it is full of threatening possibilities. The effect of the sun on activities in this novel Anthills of the Savannah is traumatic and a lot of damages are brought to the people. This terrible effect of the sun to the citizens of Abazon is not what Ikem can comprehend the reason why it is so. The people do not know the crime they have committed that they are treated as such by 'the Great Carrier of the Sacrifice to the Almighty' (The sun). They pray and offer sacrifices to the Almighty God through the sun to look down on them with mercy. These prayers and sacrifices are offered to the sun not because the sun is the Almighty God rather he is a messenger that will take the offerings to the Almighty God, the Creator.

In contrast to the terrible part the sun plays to the damage of the whole creation in Anthills of the Savannah; man, animals, trees, grasses, birds, clouds, etc, the sun is also seen as giving inspiration to people. Ikem Oshodi, one of the major characters in the novel, composed this 'Hymn to the Sun' because he sees his victory as the work of the sun. He composed a hymn to the sun to celebrate his victory over a taxi driver. He beats the taxi driver in the game of maneuvering for space by motorists during a severe traffic jam. Ikem is a journalist. He is invited by his friend Chris Oriko to cover a goodwill delegation from 'Abazon' at the Reception Room of the Presidential Palace. The traffic jam on the road made him to be late for several hours. Taxi drivers always win whenever there is such traffic jam in overtaking private drivers because 'owner driver will sooner concede his place than risk a dent on his smooth precious carapace' (29). Ikem broke the jinx for the first time in traffic history of the land in winning the taxi driver and that night he composed his hymn to the sun. In the hymn, the sun is severely conceptualized as 'Great carrier of sacrifice to the Almighty: Single Eye of God', 'Wide - eyed insomanic', 'Undying Eye of God', 'One-wall-neighbour to blindness' and Great Messenger of the Creator (30).

In Birago Diop's poem Omen, the sun is also portrayed as a source of protection in all stages of human life. This creative work is influenced by Diop's experiences, his early life at Dakar in Senegal through his life in France where he studied veterinary science.

'Omen' by Birago Diop

A naked sun - a yellow sun

A sun all naked at early dawn

Pours waves of gold over the bank

of the river of yellow

$A$ naked sun - a white sun

$A$ sun all naked, and white

Pour waves of silver

Over the river of white 
$A$ naked sun - a red sun

$A$ sun all naked and red

Pours waves of red blood

Over the river of red

K.E. Senanu and T. Vincent's A Selection of African Poetry (1976:33) argues that this poem is typical of Birago Diop, who is preoccupied in many of his poems with that aspect of African culture which emphasizes the importance of the guiding spirit of our ancestors. The colours of the sun symbolizes stages of his life: the dawn of his life - his childhood symbolized by 'a yellow sun', his youth by 'a white sun' and his old age by 'a red sun'. He strongly believes in the protection given him by the spirit of his ancestors against all ills. No matter the colour of the river, it blends with the colour of the naked sun; signifying that the spirits of his ancestors are always available to protect and inspire him.

Dennis Brutus' poem The Sun on This Rubble, reminds us of the former apartheid South Africa. The sun piercing its rays on the heap of earth after rain gives an impression of a respite to the blacks. The rays of the sun have the capacity of injecting new life and vigour to the crunched bodies and spirit of the people. The sun rays therefore become invigorating forces that strengthens the oppressed blacks.

The Sun on this Rubble

The sun on this rubble after rain

Bruised though we must be

Some easement we require

Unarguably, though we argue against desire

Under jackboots our bones and spirits crunch

forced into sweat-tear-sodden slush

- now glow-hipped by this sudden touch

- Sun-striped perhaps, our bones may latter sing

or spell out some malignant nemesis

Sharpevilled to spearpoints for revenging

but now our pride-dumped mouth are wide

in worldless supplications

- are grateful for the least relief from pain

- like this sun on this debris after rain

The time African people go to work in their farms and the time to close for the day's work are also known throw observing the positions of the sun. Peter Abraham in his Mine Boy depicts this when he says:

... they went into the fields to look after their crops. And when the sun was going down they came back and looked for their beer but their beer was gone. And they looked for Custom but he had gone too (11).

The sun is also used in Asare Konadu's A Woman in her Prime to show that African people have specific times for burial especially the people of Ghana. The burial of Yaw Boakye is done when the sun is setting. This is because Brenhoma people believe that the shadow of the coffin falling across a person draws him closer to his own death.

The sun was setting; its red glow would soon deepen and persist for considerable length of time before darkness finally closed in. No shadows are cast at the time of sunset glow; therefore no one needs fear that the coffin's shadow will fall across him to drive him closer to his own death.

The time for burying Yaw Boakye had come. As if this was what she had been waiting to do all day, Pokuwaa arose to watch the coffin onto the shoulder of the bearers (72). 


\section{The representation of the Moon in African literature}

In Chinua Achebe's Arrow of God, it is believed by the people of Umuaro that the relationship they have with their religious and agricultural existence is designed by the gods. Ezeulu, the protagonist of the novel and the chief priest of Ulu is the custodian of the timetable of the events of the people. This timetable of events depends on the moon. His hut is therefore built differently from other men's hut so that it would be easier for him to do his sky watching.

His obi was built differently from other men's hut. There was the usual, long threshold in front but also a shorter one on the right as you entered. The eaves on this additional entrance were cut back so that sitting on the floor Ezeulu could watch that part of the sky where the moon had its door (1).

In African society the moon, like the sun is sometimes deified. People pour libation to the Moon on its mere appearance (appearance of the new Moon). Some just utter their wishes to the Moon for protection. A good example of this is seen in Chinua Achebe's Arrow of God where the new moon is welcomed by the people in Ezeulu's compound. The people utter their wishes to the Moon for protection: 'Moon may your face meeting mine bring good fortune' (2). In Achebe's Arrow of God, the appearance of the Moon is also used to show the time of planting and harvesting.

In some African cultures dances are done under full Moon. Sometimes these dances are for entertainment, burial rites or fetish rites done annually to ward off the year and welcome the New Year. In Elechi Amadi's The Concubine, a dance was held in the village arena in honour of Emenike one month after his death.

One evening, about one month after Emenike's death, an oduma dance was held in the village arena. The night was clear as it had rained heavily the previous day. The moon was full. The shadows of the shade tress were almost as sharply defined as on a bright sunny day (26).

The song composed in Emenike's honour was sung with unavoidable melancholy. The tune was charming but the words were sad. Even Wakiri's usually clear voice was tremulous as he sang the first stanza.

Do you know that Emenike is dead? Eh - Eh - Eh,

We fear bug wide world; Eh - Eh - Eh,

Do not plan for the morrow, Eh - Eh - Eh,

The instrument took over for only a short time and few people danced (28).

In Gabriel Okara's Moon in the Bucket, the moon is used as a symbol of peace and concord. Okara was born in Nembe in the Rivers States of Nigeria. He witnessed the Nigerian Biafra Civil War and this influenced his war poems. Through many of his poems, he reflects on the uncertainties and the frustration of human life. His war poems show his deep concern for the violence and ravages of war and the destruction of human life. Ordinarily Okara is a peaceful and quiet man and so the war sharpened his longing for harmony and his hatred for division that plague human relationships (Senanu and Vincent 1976). Okara therefore in this poem uses the moon as a symbol of peace to reflect generally the culture of his people; their high esteem for the Moon.

Moon in the bucket

Look!

Look out there

In the bucket

with water unclean

Look!

A luminous plate is floating -

The moon dancing to the gentle night wind 
Look all you who shout across the wall

With a million hates look at the wall

It is peace unsoiled by the murk

and dirt of this bucket war

The Moon is also represented in African Literature as a means of idiomatic expression of terrible happenings. This is clearly seen 'in the Structural Role of Moon' in The Poor Christ of Bomba. The third part of this novel by Mongo Beti examines the structural role of the Moon - the full Moon in September. Beti uses Denis' expression of the full moon that is swollen and pregnant to portray the level of failure of the Parish Priest in all his seen 'hard works' in Bomba (the sixa is used as example).

It (the sexual harassments, abuses, and the diseases contacted from these actions) reminds me of the appearance of the full moon in September, when my mother was still alive and I was very young. She said to me: 'look at the moon. Isn't it larger than all other moons? As if it were swollen? Well, that's because it's with child! It's carrying the baby which it bears every year, just at this season: the rains ... (167)

The Moon looking as if it is swollen because it is with child depicts the way the sky entities are used in African tradition as idiomatic expressions. When a moon is said to be pregnant it only means that terrible things are going to happen. It is used in the context because The Poor Christ of Bomba examines the roles of religion in colonialism; the colonial masters' religious operation brings more harm than good to the people of Bomba. The presentations are steeped in irony as Beti seeks to invalidate the assumption of superiority in everything which colonialists used as a justification of their graven trampling on other people's customs and beliefs.

\section{The representation of the stars in African literature}

In Peter Abraham's Mine Boy, Xuma sees his dead mother as one of the stars that fill the sky. The novel depicts the sufferings of the blacks during the apartheid in South Africa. Xuma came from the North to the city looking for greener pasture. The ways of the city are strange. Things are not the same as it is in the North where he comes from. He decides to stare at the Milky Way. The object of his thought suddenly changes to the stars. He sees his dead mother as one of the stars that fill the sky.

The ways of the city are truly strange, He decided as he stared at the Milky Way

The old folk said that those who died became stars. He wondered if his mother was a star and whether she was up there and whether she could see him.

'Mother. Mother, are you there among the stars? And can you see me?'

He chuckled to himself, Fool! to be talking at the stars. It reminded him of his dog who always bayed at the moon. As if the moon cared (53)

Even though Xuma sees himself as a fool to be talking to the stars, this passage brings out clearly the belief of his people that dead people become stars. He only sees himself as a fool because his mother will not come out physically to relieve him from his traumatic strange experiences in the city. It can also mean that his mother who has joined his ancestors has also ceased to care for the living. Their ancestors as stars are there in the sky while they are suffering all these humiliations from the whites. There is more joy in the rural life but he is now far from this joy. One thing that is pointed out here is that Africans believe that their ancestors appear and shine as stars in the sky and they drive joy watching the sky to see these stars. The stars are his people's source of stability and emotional anchor. The more reason why Xuma stares to the sky is because he wants a moment of real enjoyment which he believes the stars will offer him. These stars will give him not only inspiration but also solutions to his problems. 
Also in Titus Chukwuemeka Nwosu's Star dust, he uses 'dust-laden star' as a symbol of Nat his friend. This brings out clearly the belief of Igbo people that dead heroes are seen as stars. The title of this poem can be taken to mean the remains of a star after it has burnt itself out. The implication of this title is death. This poem is an elegy bewailing the death of a courageous and noble friend who died suddenly in an air-raid during the Nigerian civil war.

Star dust

\author{
(for Nat) \\ Harvest is no blessing \\ When death is the crop; \\ He was both the crop and the harvest \\ The plough-man and the ploughshare \\ That cut and was cut both ways! \\ Full armed warrior hammered out of steel; \\ Muscled eye of the embattle bread. \\ Now no more shall your sun \\ Belch out fire - bolt \\ Nor mortar music mob your ears \\ Nor your amour out shine others! \\ Dust-laden star that gripped ...
}

\title{
5. Conclusion
}

It is important to note that the representation of the sky entities in these African selected texts depicts the social values of the Sun, Moon and Stars in African societies. Through the worship of these entities, African people believe that they are communicating with the Almighty Creator. Due to the fact that African people didn't have clock, they took time to study the position of the sky entities to interpret the time - the day, night, calendars for agricultural seasons, festive seasons etc. The social values of the sky entities conduce to their being represented in literature. Through the use of literary devices used in portraying these sky entities, the themes in the selected texts are enriched because Art is life and the sky entities have the qualities of life giving.

\section{Acknowledgements}

I am grateful for the partial support from the SOC that enabled me to participate.

\section{References}

Abraham, P. 1946, Mine Boy (London: Heinemann)

Achebe, C. 1988, Anthills on the Savannah (Ibadan: Heinemann)

Achebe, C. 1989, Arrow of God (Ibadan: Heinemann)

Amadi, E. 1966, The Concubine (Ibadan: Heinemann)

Konadu, A. 1998, A Woman in her Prime (Ibadan: Heinemann)

Obiechina, E. 1975, Culture, Tradition and Society in the West African Novel (Cambridge: Cambridge University Press), p. 47 
Obiechina, E. 1980, 'Peter Abraham's Mine Boy' in Okike Educational Supplement no. 2.

Opata D. U. 2008, in African cultural astronomy: Current Archaeastronomy and Ethnoastronomy

Research in Africa J. Holbrook, R. Medupe, \& J. Urama (eds) (Berlin: Springer) p. 217

Senanu, K. E. \& Vincent, T. 1976, A Selection of African Poetry (London: Longmans)

Westling, L. et al. 1999, The World of Literature (New York: Prentice-Hall Inc), p. 73 